\title{
Anthós
}

\section{Tyranny, Marriage, and a New Market}

William Holden

Portland State University

Follow this and additional works at: https://pdxscholar.library.pdx.edu/anthos

Part of the English Language and Literature Commons

Let us know how access to this document benefits you.

\section{Recommended Citation}

Holden, William (2011) "Tyranny, Marriage, and a New Market," Anthós: Vol. 3: Iss. 1, Article 2.

https://doi.org/10.15760/anthos.2011.1

This open access Article is distributed under the terms of the Creative Commons Attribution-NonCommercialShareAlike 4.0 International License (CC BY-NC-SA 4.0). All documents in PDXScholar should meet accessibility standards. If we can make this document more accessible to you, contact our team. 
William Holden

$6 / 14 / 11$

Studies III: Science

Dr. Kathleen Merrow

Tyranny, Marriage, and a New Market

This will be an explication of John Stuart Mill's Autobiography (1873) along with a discussion of its relationship to the works of Jean Jacques Rousseau in regards to the models of gender and womanhood painted by each thinker in his texts. First, I will offer a quantified taxonomy of several formal structures in Mill's text, including a summary of the uses of the phrase "my father" alongside a summary of the instances of Mill's claims of having read an author. Next, I give a summary of the uses of the phrases "my wife" and "my daughter" alongside a discussion of the instances in which Mill discusses his own writings and their placements in the text. Following this, I include a brief overview and conclusion of the meaning shaped by these formal structures to argue for the structural importance of a particular passage in the text in which John Stuart Mill introduces his wife, Harriet (Mill 146-148). Next, drawing from secondary sources, I offer an account of Rousseau's philosophy and political program for women, followed by a discussion of the influence of Rousseau's thinking on John Stuart Mill's own representation of Harriet in his text. I will show that Rousseau's understanding of women as biologically equivalent yet inferior to men are extremely pervasive in Mill's understanding and use of women in Autobiography. Following this, I will pull from Mill's essay "The Subjugation of Women" (1869) and discuss the implications of this work for Mill's representation of women in Autobiography. By doing this, I will show that John Stuart Mill, while retaining several aspects of Rousseau's philosophy, reorganized gender roles and marital power dynamics in order 
to accommodate the fledgling free market ideology and bourgeois social order of the $19^{\text {th }}$ century.

First, to understand the representation of Mill's wife in this text we must understand the representation of his father. There are seven chapters in this text. Chapter five, entitled "A Crisis in my Mental History . One Stage Onward” (Mill, Autobiography 111-144), marks a turning point in his thinking. It is in this chapter that "the whole foundation on which my [Mill's] life was constructed fell down" (Mill, Autobiography 112). The beginning of the chapter also marks, roughly, the center of the text by page volume. As I will show, this chapter and Mill's mental "crisis" also help to shape the role of his wife and father as formal structures in the text. There are a total of 152 instances of the phrase "my father" in the Autobiography. Of these, 83\% occur before chapter five, $9 \%$ take place inside of chapter five, and the remaining $8 \%$ occur in chapters six and seven. The decline of the use of this phrase is consistent with and evident of the fading importance of Mill's father as a part of his education. A similar pattern can be seen with Mill's use of the texts that he has read. There are a total of 157 direct references to authors that Mill has read throughout the text. Of these, $84 \%$ occur in chapters one through four, $12 \%$ occur inside of chapter five and $4 \%$ occur in the remainder of the text. There is a fairly even pattern in the decline of the usage of the phrase "my father" and the instances in which Mill discusses reading other texts. There is thus a correlation between these two forms of evidence; his father represents an earlier time in his life, and also an earlier form of education and lifestyle: reading. As formal structures, these are less prevalent after Mill's crisis in chapter five.

The use of the phrase, "my wife" does not occur until chapter seven (Mill, Autobiography 182), however there is some discussion of his wife, Harriet, earlier in the text, and she is introduced at the outset of chapter six, entitled "Commencement of the Most Valuable 
Friendship of my Life. My Father's Death. Writings and Other Proceedings up to 1840” (Mill, Autobiography 145). Still, quantifying the use of the phrase "my wife" will give us some insight into Mill's use of Harriet as a formal structure. There are a total of 4 instances of said phrase in this text. At relatively the same position in the text, discussion of Mill's stepdaughter becomes prevalent. Passages involving his stepdaughter-almost without exception referred to simply as his “daughter"- do not occur until chapter seven (Mill, Autobiography 196), but there are a total of eight instances of the phrase "my daughter" throughout the text. As the discussion of Mill's wife and daughter present themselves in the text, the passages wherein Mill discusses his own writings increase as well. There are a total of 65 pages in which Mill discusses his own writings. Of these, $17 \%$ occur in the chapters preceding chapter five, $13 \%$ occur within chapter five itself and the remaining $70 \%$ occur in chapters six and seven. We therefore have another correlation between these two sets of data; the rise in uses of "my wife," "my daughter" and the instances of Mill referencing his own writings are parallel and occur, as formal structures, primarily after Mill's crisis in chapter five.

In order to better understand these patterns, we must now turn to characterization. In regards to Mill's father, we are told that he was trained as a preacher in the "Scottish Church... but never followed the profession" (Mill, Autobiography 26) and that he held "opinions, both in politics and in religion, which were... odious to all persons of influence" (Mill, Autobiography 27). His father is also described as being very cold and unemotional in his pedagogy, which contained remnants of "the old brutal and tyrannical system of teaching" (Mill, Autobiography 59). The character of Mill's father is consistently one without emotion. Mill tells us, "[t]he element which was chiefly deficient in his moral relation to his children was that of tenderness" (Mill, Autobiography 59) and that his "father's teachings tended to the undervaluing of feeling" 
(Mill, Autobiography 97). Mill's mental crisis, in fact, is attributed to his father's flawed pedagogy and undervaluation of emotion. "My education, which was wholly his [James Mill] work, had been conducted without any regard to the possibility of its ending in this result" (Mill, Autobiography 113).

On the other hand, Harriet and her daughter's characters develop a sharp contrast from the characterization of Mill's father. Mill carefully describes his wife's "rich and powerful nature" and her "type of feminine genius" (Mill, Autobiography 146). Her "complete emancipation from every kind of superstition" resulted "not from the hard intellect but from strength of noble and elevated feeling" (Mill, Autobiography 146). He even describes the ways in which she "reached her opinions by the moral intuition of a character of strong feeling," though he himself had arrived at "the same results by study and reasoning" (Mill, Autobiography 148). Harriet's daughter, Helen, is described in very similar terms. She is "the inheritor of much of her [Harriet] wisdom, and of all her nobleness of character, whose ever growing and ripening talents from that day to this have been devoted to the same great purposes" (Mill, Autobiography 196). Mill's wife and daughter also occupy an almost identical structural position in the text. Harriet and Helen's emotional characters are in direct contrast to that of Mill's father. While the elder Mill is cold and over rational, Harriet and Helen are kind and intuitively good. While the elder Mill forces the young Mill to read classical texts (Mill, Autobiography 31-35), Harriet and Helen are directly involved in the production of new ones (Mill, Autobiography 183-184, 186-189, 196198, 222-225, 229). Mill has progressed throughout the text from an infancy that is associated with his father, reading and antiquity, on to an adulthood associated with Harriet and Helen, writing and modernity. The placement of Harriet's introduction is also important to note. She arrives in the text immediately following the crisis depicted in chapter five. After having come to 
understand the deficits of his lifestyle and education associated with his father, Harriet's presence is made known. Thus, the importance of Harriet's introductory passage (Mill, Autobiography 145-148) becomes clear: she is the pivot by which John Stuart Mill shifts his life into its final and ideal stage.

The formal structures of Mill's wife and daughter are clearly positioned to replace the formal structure of his father in this text. At the same time, Harriet's presence is also understood to complete Mill's own identity. Her appearance directly after his own crisis allows him to reshape himself and his own agency in a different way. The presentation of Harriet as "a woman of deep and strong feeling, of penetrating and intuitive intelligence" (Mill, Autobiography 146) depicts her as a primarily moral being, in opposition to Mill's more rational nature. "Her unselfishness was not that of a taught system of duties, but of a heart which thoroughly identified itself with the feelings of others..." (Mill, Autobiography 147). In addition, she is praised for her "genuine modesty combined with the loftiest pride; a simplicity and sincerity which were absolute..." (Mill, Autobiography 147). This highly gendered language is paired with the notion that her intuition is somehow equivalent to his intellect (Mill, Autobiography 148). Harriet is meant to complete John Stuart Mill's being, and it is only after she arrives that, as we have seen, discussion of his own writings begins to greatly increase alongside a decrease in instances of his own reading. His own agency is induced by the presence of Harriet, and it is through her that he begins to seriously produce. Production as the opposite of consumption is absolutely central to Mill's self-representation following his crisis and his break from his father's education. By now reshaping himself as a complete being whose reason, cultivated by his father, is completed by Harriet's feminine intuition, Mill stresses the importance of a new kind of social order. The new 
Mill is a producer. He creates texts, he wages battles in the House of Commons (Mill, Autobiography 206-226) and is now capable of forming his own opinions and ideas.

This notion of femininity, projected by Mill on to Harriet, of a woman whose function is to privately maintain the public agency of her husband has its own roots in the $18^{\text {th }}$-century vision of the role and nature of women, exemplified by Rousseau's writings and his depictions of women's role in the political sphere. Before this historical connection can be made clear, I will first offer a brief historical context for Rousseau's work regarding the role of women and I will then offer a brief summary of Rousseau's understanding of the role of women in society. The newfound political force of Enlightenment republicanism brought with it an era of highly tumultuous discourse on gender roles. As Joan Landes has argued, "women were confronted with a new, and hitherto relatively inconsequential, source of discrimination, the constitutional denial of women's rights under bourgeois law" (Landes 11). This era ushered in a profoundly different understanding of the biological difference between men and women. "The reproductive organs went from being paradigmatic sites for displaying hierarchy, resonant throughout the cosmos, to being the foundation of incommensurable difference..." (Laqueur 149). It is from the midst of this effort of "gendering the public sphere" (Landes 2) that Rousseau's writings on gender roles emerge.

Rousseau, according to Landes, "[p]erhaps more than any other writer of the eighteenth century... agonized over the appropriate role for women" (Landes 66). As is true of much of Rousseau's political and social program, an appeal to the state of nature was central to his argument about gender roles. In the state of nature depicted by Rousseau is his Discourse on the Origin of Inequality (1755), "[m]ale and female copulated, with no preference for one individual over another" (Okin 109). The responsibility of child rearing in nature, however, falls solely on 
the female because she "is well equipped to nourish her child and feed and protect herself... since she can carry it [child] easily and without slowing her own pace" (Okin 109). As Rousseau superimposes these natural archetypes back on to the world of the fledgling Enlightenment, he concludes, as Joan Landes put it, that “[w]oman's duty consists of subordinating her independent aims and interests to a higher goal, the ethical life of the community" (Landes 69). Woman's role in society, therefore, must be completely apolitical and completely domestic. This stems from a theological model, one in which God has "given reason to man, and modesty to woman in order to restrain them" (Okin 117). Thus, it is "the feminine which is out of place in the public, representational arena, as that place belongs properly to the masculine" (De Magnin 54). The political coverture, then, is completely explicit: men are political beings while women are domestic. The social power exerted by women is actually done so through the domestic sphere. Rousseau declares: "[a]miable and virtuous women citizens, it will always be the fate of your sex to govern ours. Happy it is when your chaste power, exercised only within the conjugal union, makes itself felt only for the glory of the state and the public happiness" (Rousseau 9)! The fabric of social order includes women exclusively through their ability to control men through their sexuality. Women are meant to "assert on every occasion the rights of the heart and of nature for the benefit of duty and virtue" (Rousseau 9). Rousseau has created a gendered duality between men and women wherein the male role is political and public while the female role is domestic and private. Women's separate social role from men has its origins, according to Rousseau, in the formation of the family. In ancient times, "[e]ach family became a little society all the better united because mutual attachment and liberty were its only bonds; and it was then that the first difference was established in the lifestyle of the two sexes, which until then had had only one. Women became more sedentary and grew accustomed to watch over the hut and the 
children, while the man went to seek their common subsistence" (Rousseau 48). This is not only a political form of coverture, as postulated by John Stuart Mill's father, but rather a coverture of consciousness. Because the division of labor requires men to be the public member of the family, they must then represent the entire family as a political entity. The woman, therefore, functions to provide maintenance for the "little society" of the family. In the home, she assures that the state of the family is in order, and to neglect this place sacrifices the fabric of society as Rousseau conceives it. In the emerging republican ideology of Rousseau's time, the family is clearly conceived of as a microcosm of an aristocracy wherein the husband functions as a king while the wife and children function as his subjects. The wife is understood as a function of the husband through "conjugal union," and allows his own political prosperity and influence to flourish.

As we have seen, the characterization of Harriet in John Stuart Mill's Autobiography very closely matches the description of a proper woman in Rousseau's work. We must not neglect, therefore, the agency allowed Mill as a producer once Harriet and Helen become active characters in the text. As opposed to Rousseau's coverture of consciousness, Mill understands coverture in terms of intellectual production. He frequently discusses his wife and daughter's roles in assisting him in his writings (Mill, Autobiography 183-184, 186-189, 196-198, 222-225, 229). Indeed, Mill's insistence that his “published writings were as much her [Harriet's] work as mine" speaks volumes to the notion of intellectual coverture represented in this text (Mill, Autobiography 184). The passage in which Harriet is introduced (Mill, Autobiography 145-148) includes several themes that correlate to Rousseau. Mill's assertion that "her mental progress and mine went forward in complete companionship" mirrors this notion of social coverture (Mill, Autobiography 148). Mill's strength apparently lies in "the uncertain and slippery intermediate 
region, that of theory, or moral and political science" (Mill, Autobiography 148). It is through Harriet, however, that he has "derived" a "wise skepticism," which, though "it has not hindered" him, has kept his mind "not only open to admit, but prompt to welcome and eager to seek... any prospect of clearer perceptions and better evidence" (Mill, Autobiography 148). In terms of Mill's life's work, the structural importance of this passage is very much related to Rousseau's notion of women in the public sphere: Harriet, and later Helen, assist Mill in fulfilling his duties as a citizen and as an educated man.

It is, however, a mistake to understand this structure simply in terms of Rousseau's social agenda. Mill depicts a very different function for women in society. In his essay "The Subjugation of Women," Mill offers a fairly comprehensive vision of women's proper role in society. He claims to reject visions such as Rousseau's outright, decrying the "legal subordination of one sex to the other" as "wrong in itself, and now one of the chief hindrances to human improvement" (Mill, "Subjugation” 119). Mill postulates a "principle of perfect equality, admitting no power or privilege on the one side, nor disability on the other" (Mill, "Subjugation" 119). According to Mill, the legal relationship between sexes was comparable to that of slavery in that one member is completely subordinate to a master (Mill, "Subjugation" 123). In addition, the relationship between husband and wife has an "analogous relation of parent and child..." (Mill, "Subjugation" 141). He goes on, "The truth is, that the position of looking up to another is extremely unpropitious to complete sincerity and openness with him. The fear of losing ground in his opinion or in his feelings is so strong, that even in an upright character, there is an unconscious tendency to show only the best side, or the side which, though not the best, is that which he most likes to see..." (Mill 141-142). The authority of one figure over the other is what creates a legitimate comparison for Mill between father/son and husband/wife. The shift in Mill's 
Autobiography, then, from the former relationship, associated with consumption, to the latter relationship, associated with production, must be understood within these terms. In the father/son relationship, there is a tyranny, and Mill thus characterizes his father as stern and domineering. The shift to the husband/wife relationship, then, is marked not by oppression but by symbiosis whose social order will settle itself "lest nature should not succeed in effecting its purpose..." (Mill "Subjugation" 143). For Mill, "What women by nature cannot do, it is quite superfluous to forbid them from doing... Whatever women's services are most wanted for, the free play of competition will hold out the strongest inducements to them to undertake. And, as the words imply, they are most wanted for the things for which they are most fit; by the apportionment of which to them, the collective faculties of the two sexes can be applied on the whole with the greatest sum of valuable results” (Mill, “Subjugation” 143-144).

The notion of division of labor between sexes, therefore, is consistent with Rousseau's vision. However in contrast to Rousseau, Mill's model of women is meant to support the male citizen and to help him produce. The fledgling ideology of free market capitalism is completely central to Mill's understanding of the function of the family; through Harriet, Mill not only becomes a producer, but it is through her assistance that he can appropriately contribute to society. There is even a discreet criticism of the notion of family as based upon the aristocratic state. In search of a proper and more distributed power dynamic inside of marriage, Mill appeals to "partnership in business" as a model for the husband/wife relationship. "If the law dealt with other contracts as it does with marriage, it would ordain that one partner should administer the common business as if it was his private concern; that the others should have only delegated powers; and that this one should be designated by some general presumption of law, for example as being the eldest" (Mill, "Subjugation" 155-156). For Mill, in opposition to Rousseau's vision, 
the "feminine genius" (Mill, Autobiography 146) is meant to be utilized rather than scorned. The program of coverture is moved away from one of political representation, as offered by Rousseau. By contrast, Mill offers us a vision of intellectual coverture; the family, headed by a patriarch, is understood in terms of it's productive and capitalistic value. In this model, women have become a resource to be exploited rather than a problem to be contained. The market as a system of agency is used to redefine appropriate gender roles in marriage and indeed, the structure and function of marriage itself.

As I have shown, the way that Harriet and Helen are represented as formal structures in this text must be understood in an historical context. By examining these formal elements, I have shown the ways in which Mill's wife and daughter are meant to replace his father in terms of power dynamics: this is a move from an explicitly hierarchical power structure, that is, one of domination, to a nominally egalitarian power structure whose hierarchy is determined by the “free play of competition." By examining the features that Mill shares with a thinker like Rousseau on the subject of gender roles, we can see that the notion of female nature as domestic proliferates Mill's structuring of women's role in society. Mill's notion of market capitalism as a tool for social order depends upon this notion of gendered nature to stabilize the family as a political unit. The problem of coverture, therefore, does not cease to exist by its elimination from the legal sphere; Mill's insistence on abandonment of legal coverture is replaced by an intellectual one. For Mill, "[n]ot a word can be said for despotism in the family which cannot be said for political despotism" (Mill, "Subjugation” 150). The shift in Mill's text, from his father to his wife and daughter, may be understood, then, as a political and historical allegory; rather than depending upon heredity for social order and power structuring, Mill argues that by appealing to nature, we can allow the market to sort out the problems of order that are presented by the new, 
bourgeois society. As we have seen, the latter of these options is presented as conducive to agency, the core notion of which is also tied to the market: production. By reshaping himself in the context of the new social order, capitalism, Mill legitimates himself as a participant in society at large and in the body politic. 
Works Cited

De Magnin, Peggy Kamuf. "Rousseau's Politics of Visibility.” Diacritics 5.4 (1975): 51 56. Web. 6 Apr. 2011.

Landes, Joan B. Women and the Public Sphere In the Age of the French Revolution. Ithaca, New York: Cornell University Press, 1988. Print.

Laquer, Thomas Walter. Making Sex: body and gender from the Greeks to Freud. Cambridge, Massachusetts and London, England: Harvard University Press, 1990. Print.

Mill, John Stuart. Autobiography. London, England: Penguin Books, 1989. Print.

---. "The Subjugation of Women.” On Liberty and other Writings. Ed. Stefan Colloni. Cambridge, UK: Cambridge University Press, 1989. 117-217. Print

Okin, Susan Moller. Women in Western Political Thought. Princeton, New Jersey: Princeton University Press, 1979. Print.

Rousseau, Jean Jacques. Discourse on the Origin of Inequality. Indianapolis: Indiana: Hackett Publishing Company, 1992. Print. 